\title{
Evaluation of forearm arterial repairs: Functional outcomes related to arterial repair
}

\author{
Musa Kemal Keleş, M.D., ${ }^{1}$ Tekin Şimşek, M.D., ${ }^{2}$ Veysel Polat, M.D., ${ }^{3}$ \\ Engin Yosma, M.D., ${ }^{2}$ Ahmet Demir, M.D. ${ }^{2}$
}

\begin{abstract}
1Department of Plastic, Reconstructive and Aesthetic Surgery, Dışkapı Yildirim Beyazıt Training and Research Hospital, Ankara-Turkey ${ }^{2}$ Department of Plastic Surgery, Ondokuz Mayıs University Faculty of Medicine, Samsun-Turkey

${ }^{3}$ Department of Radiology, Ondokuz Mayıs University Faculty of Medicine, Samsun-Turkey
\end{abstract}

\begin{abstract}
BACKGROUND: There are few studies of single forearm arterial injury repair that compare long-term results of intact and obliterated forearm arterial repair. Aim of the present study was to compare long-term results of forearm arterial repair using Quick Disabilities of the Arm, Shoulder and Hand (QuickDASH) score and color Doppler ultrasound (CDUS).

METHODS: Records of 166 consecutive patients with forearm arterial injury were reviewed, and 30 patients with same injury (ulnar artery, ulnar nerve, and tendon injuries at flexor zone V) were called back for CDUS and QuickDASH scoring. Patients evaluated with CDUS were divided into 2 groups according to results: patent vessels (Group I) and obliterated vessels (Group 2), and statistical analysis was performed to compare QuickDASH scores of groups.
\end{abstract}

RESULTS: Difference in QuickDASH scores was statistically significant: Group I had lower score (24.27) than Group 2 (36.34), indicating better outcome in patients with patent vessels.

CONCLUSION: Vascular repair that achieved vessel patency led to better functional outcome with lower QuickDASH score and less cold intolerance.

Keywords: Cold intolerance; forearm injury; functional outcome; nerve injury; vascular injury.

\section{INTRODUCTION}

Arterial injuries at the forearm level form a relatively small number of total injuries in the upper extremities. Stab wounds and injuries caused by broken glass constitute primary causes of this type of injury. ${ }^{[1]}$ Arterial bleeding along axis of the wound, pulselessness distal to the injury, and positive Allen test are sufficient to diagnose problem. However, color Doppler ultrasonography (CDUS) can be used to confirm diagnosis. ${ }^{[2]}$ Angiography, which is an invasive test that can be performed to diagnose arterial problems, is impractical method for diagnosing acute trauma in patients. ${ }^{[3]}$ Careful

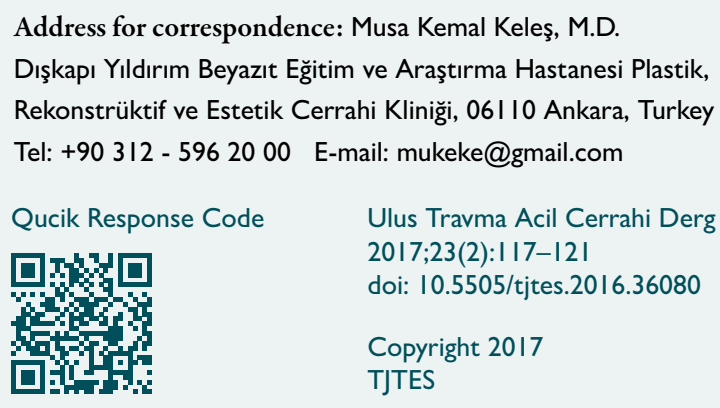

exploration of wound edges and visual identification of the 2 ends of the transected vessels can confirm diagnosis.

Tendon, nerve, muscle, and even bone injuries frequently accompany arterial injuries. Although functional recovery directly depends on severity of accompanying injuries, decreased arterial flow can also negatively affect wound healing and functional recovery. ${ }^{[1]}$ Twenty years ago, occlusion after vessel repair was frequent, and ligature of arteries in patients who had well-perfused hand was reliable method. ${ }^{[1]}$ However, present widespread use of surgical loupes and improvements in technical facilities have raised success rate of surgical repair by almost $100 \% .{ }^{[4]}$

Although isolated vessel injuries of the forearm are a problem frequently encountered by plastic surgeons, long-term data in the literature concerning this type of injury are quite limited. Most of them fall under the heading of "total upper extremity injuries." The aim of this study was to analyze demographic data and evaluate functional outcome of procedures on hands in patients with at least 6 months of follow-up. Quick Disabilities of the Arm, Shoulder and Hand (QuickDASH) score was used for this evaluation. QuickDASH is a self-report ques- 
tionnaire designed to measure physical function and symptoms in people with any of several musculoskeletal disorders of the upper limb.

\section{MATERIALS AND METHODS}

Review of 166 consecutive cases of repair of vessel injury in the forearm region performed between October 2006 and August 2014 was conducted. Emergency operation was performed within 5 days of injury. Before surgery, informed consent was obtained from all patients. All operations were performed by experienced plastic surgeons or hand surgeons. All anastomosis was performed under microscopic magnification with interrupted 9-0 Prolene suture (Ethicon, Inc., Cornelia, GA, USA). Use of Fogarty catheter (Edwards Lifesciences Corp., Irvine, CA, USA) was avoided, as doing so may damage the endothelium. Postoperatively, anastomosis was examined for patency with hand-held Doppler US. Only painkillers and antibiotics were administered in postoperative period. Patient demographic details, etiology, accompanying injuries, cold intolerance, and QuickDASH scores were documented. Evaluation of arterial flow was performed in 30 patients who had both ulnar artery and ulnar nerve injury with accompanying tendon injury at level of the wrist that had been repaired at least 6 months prior. CDUS were performed using Aplio XG SSA-790A (Toshiba Medical Systems Corp., Otawara, Japan) device, which employs $12 \mathrm{MHz}$ linear probe. US filtering and gain were adjusted to provide greatest level of detail without artifacts. Doppler insonation angle was set to less than 60 degrees during velocity measurement. Flow parameters, such as diameter of the injured and contralateral ulnar artery and peak systolic maximum velocity (Vmax) of both arteries, were measured in each patient. Following CDUS, patients were divided into 2 groups: non-obliterated artery group (Group I) and obliterated artery group (Group 2). Distal blood flow of non-obliterated arteries and contralateral arterial blood flow at the same level were also evaluated, and data obtained from QuickDASH scores of Groups I and 2 were compared.

All data were statistically analyzed with SPSS 20 software (IBM Corp., Armonk, NY, USA) using non-parametric MannWhitney $U$ and chi-square tests. $P<0.05$ was adopted to represent statistically significant difference.

\section{RESULTS}

\section{Patient Demographics}

Total of 144 male and 22 female patients with mean age of 30 years (range: $1-76$ years) were included in the study. Repair of 179 arteries were conducted in 166 patients. Most frequent mechanisms of injury included laceration from stabbing, glass, circular saw, or grinder (162 cases). Majority of repaired arteries consisted of isolated ulnar artery injury with accompanying nerve and tendon injuries (I I 4 vessels). Among accompanying lesions, isolated ulnar nerve injury in
73 patients formed largest group. Thirty-seven patients had more than I nerve injury (ulnar, median, radial). Whereas 155 (93.37\%) vessels were repaired directly, II (6.63\%) necessitated vein grafting. Most patients had right forearm injury (105 patients), and most injuries were located in one-third distal part of the forearm (143 patients). Only 2 patients received concomitant fasciotomy. No amputation was performed. Demographic results are summarized in Table I.

\section{Color Doppler Results}

Of 30 patients evaluated, Group I comprised 23 patients who had patent artery at least 6 months after the operation and Group 2 was made up of 7 patients who had obliterated arteries. Seven of 30 arteries were occluded, including 5 vein grafts and 2 primary repairs. Mean patency rate of $76.66 \%$

Table I. Demographic data of the patients

\begin{tabular}{|c|c|c|c|}
\hline & $\mathbf{n}$ & $\%$ & $\begin{array}{c}\text { Mean } \pm S D \\
\text { (Range) }\end{array}$ \\
\hline Patients (Total) & 166 & & \\
\hline \multicolumn{4}{|l|}{ Gender } \\
\hline Male & 144 & 86.74 & \\
\hline Female & 22 & 13.25 & \\
\hline Age (years) & & & $\begin{array}{c}30 \pm 14.66 \\
(1-76)\end{array}$ \\
\hline \multicolumn{4}{|l|}{ Traumatic event } \\
\hline Laceration & 162 & 97.59 & \\
\hline Blunt trauma & 4 & 2.4 & \\
\hline \multicolumn{4}{|l|}{ Repaired artery } \\
\hline Radial & 38 & 22.89 & \\
\hline Ulnar & 114 & 68.67 & \\
\hline Both & 13 & 7.83 & \\
\hline Brachial & 1 & 0.6 & \\
\hline total & 179 & & \\
\hline \multicolumn{4}{|l|}{ Coexisting nerve/bone injury } \\
\hline Ulnar nerve & 73 & 43.97 & \\
\hline Median nerve & 16 & 9.63 & \\
\hline Radial nerve & 15 & 9.03 & \\
\hline Both nerves & 37 & 22.28 & \\
\hline No nerve & 24 & 14.45 & \\
\hline Bone & 1 & 0.6 & \\
\hline \multicolumn{4}{|l|}{ Affected arm } \\
\hline Right & 112 & 67.46 & \\
\hline Left & 53 & 31.92 & \\
\hline Bilateral & 1 & 0.6 & \\
\hline \multicolumn{4}{|l|}{ Surgical procedure } \\
\hline End-to-end anastomosis & 168 & 93.85 & \\
\hline Vein graft & II & 6.14 & \\
\hline
\end{tabular}


was established. Two of 7 patients in whom obliterated anastomosis was detected displayed collateral circulation.

Mean Vmax at distal part of anastomosis site was $42.19 \mathrm{~cm} / \mathrm{s}$ and mean luminal diameter was $1.85 \mathrm{~mm}$ in Group I. There was no statistically significant difference between mean flow rate of contralateral ulnar arteries $(45.23 \mathrm{~cm} / \mathrm{s})$ and distal part of anastomosis site $(42.19 \mathrm{~cm} / \mathrm{s})(p=0.35>0.05)$.

\section{QuickDASH Score and Cold Intolerance Results}

Average QuickDASH score was 24.27 \pm I I.50 in Group I and $36.34 \pm 7.89$ in Group 2. Difference in average QuickDASH

Table 2. Summary of QuickDASH scores, cold intolerance, and color Doppler ultrasound results

\begin{tabular}{|c|c|c|c|}
\hline Patients & $\begin{array}{l}\text { QuickDASH } \\
\text { score }\end{array}$ & $\begin{array}{c}\text { Cold } \\
\text { intolerance }\end{array}$ & $\begin{array}{c}\text { Vessel patency } \\
\text { on CDUS }\end{array}$ \\
\hline I & 11.3 & No & Patent \\
\hline 2 & 31.8 & No & Patent \\
\hline 3 & 27.2 & Yes & Occluded \\
\hline 4 & 31.8 & No & Patent \\
\hline 5 & 31.8 & No & Occluded \\
\hline 6 & 11.3 & No & Patent \\
\hline 7 & 29.5 & Yes & Patent \\
\hline 8 & 53.2 & No & Patent \\
\hline 9 & 15.9 & Yes & Patent \\
\hline 10 & 40.9 & No & Patent \\
\hline II & 13.6 & No & Patent \\
\hline 12 & 18.1 & Yes & Patent \\
\hline 13 & 29.5 & No & Patent \\
\hline 14 & 31.8 & No & Patent \\
\hline 15 & 31.8 & Yes & Occluded \\
\hline 16 & 11.3 & No & Patent \\
\hline 17 & 29.5 & No & Patent \\
\hline 18 & 15.9 & Yes & Patent \\
\hline 19 & 31.8 & No & Occluded \\
\hline 20 & 31.8 & No & Patent \\
\hline 21 & 15.9 & No & Patent \\
\hline 22 & 40.9 & No & Patent \\
\hline 23 & 40.9 & Yes & Occluded \\
\hline 24 & 40.9 & No & Patent \\
\hline 25 & 13.6 & No & Patent \\
\hline 26 & 13.6 & No & Patent \\
\hline 27 & 50 & Yes & Occluded \\
\hline 28 & 18.1 & No & Patent \\
\hline 29 & 40.9 & No & Occluded \\
\hline 30 & 18.1 & No & Patent \\
\hline
\end{tabular}

QuickDASH: Quick Disabilities of the Arm, Shoulder and Hand; CDUS: Color Doppler ultrasound. score was found to be statistically significant $(p=0.014<0.05)$. Four patients in Group I (17.4\%) reported cold intolerance and 4 patients in Group 2 (57.1\%) reported experiencing cold intolerance. Difference in cold intolerance ratio was statistically significant $(p=0.04<0.05)$. Results are summarized in Table 2.

\section{DISCUSSION}

Centers that serve military and civilian populations provide different data on age and sex distribution, etiological factors, and most commonly injured vessels of patients suffering from wrist injury. Nonetheless, it occurs more often among males, especially those in their twenties. ${ }^{[4]}$ In present series, sex and age distribution of wrist injury patients was similar to previous reports. BallardI reported that broken glass was leading mechanism of laceration injury and that most commonly observed accompanying injury was damage to the median nerve. Laceration caused by broken glass, especially those caused by punching, emerged as most frequent in our series, as well.

Fasciotomy associated with vascular injury in the forearm region has been reported at rate of $26.92 \%$ to $48 \%$ in the literature. ${ }^{[5,6]}$ In the present study, incidence of fasciotomy was lower (3.6\%) due to non-blunt trauma.

When primary vascular repairs are not feasible, repair using autologous or prosthetic grafts should be pursued. Use of prosthetic grafts remains controversial. ${ }^{[7-9]}$ They have been preferred for large forearm vessels. ${ }^{[9]}$ In our clinic, we preferred to use size-matched vein grafts harvested from the lower extremities. Graft usage ratio in this series was determined to be $11 \%$.

CDUS is noninvasive, rapid, and accurate technique to evaluate results of vascular repair, flow value, and flow characteristics. ${ }^{[10]}$ In previous studies, patency rate reported has been between $0 \%$ and $100 \%$, depending on both use of graft and magnification tools. ${ }^{[10,1]]}$ In addition, different methods have been used to evaluate patency. ${ }^{[10-12]}$ In our study, CDUS, which has several advantages, was used. ${ }^{[10]}$ Patency, flow rate, and collateral vascular development were evaluated using CDUS. Patency rate of $76.66 \%$ was found in present study; however, patency ratio reflected only small number of results, obtained from 30 patients with ulnar artery and ulnar nerve injury at level of the wrist, and 5 of these patients needed vein graft for arterial repair.

Debate continues as to whether repair of injured artery in well-perfused hand is clinically beneficial. Johnson suggested that in absence of an acute hand ischemia, ligation of the injured artery is safe and economical approach in radial or ulnar artery injuries. ${ }^{[4]}$ Sitzmann also suggested that injuries to the radial or ulnar arteries alone can be treated using ligation without adverse sequelae. ${ }^{[13]}$ Lee et al. performed arterial ligation for extensive, contaminated injuries that 
did not display hand ischemia. ${ }^{[3]}$ They also advocated ligation when it was felt arterial repair would jeopardize the patient's well-being. ${ }^{[3]}$ Ballard et al. ${ }^{[1]}$ treated almost half of their patients with single forearm arterial injuries using ligation; they compared results with patients who underwent repair, and declared that both treatment modalities led to same outcome. In cases where both arteries are transected, at least the ulnar artery should be repaired; however, if the palmar arch is not intact, both arteries must be reconstructed. ${ }^{[13,14]}$ Presence of incomplete arch in $20 \%$ of the population increases risk of ischemic changes in hands. ${ }^{[13,14]}$ McCready recommended supplying sufficient amount of blood to repair vascular damage to isolated arterial injury in an extremity, and repair of the ulnar artery, which is larger, in presence of damage to both arteries. ${ }^{[9]}$ However, in recent studies, vessel repair has been demonstrated to have better results. Basetto has suggested that anastomosis is always preferable to ligation due to more substantial loss of bone mass, muscle mass, and strength in patients who underwent arterial ligation. ${ }^{[15]}$

The literature indicates that most prominent factor in prognosis of arterial injury in the forearm is presence of accompanying nerve damage; ratio has been estimated to be as high as $58 \%{ }^{\left[{ }^{[1]}\right.}$ Ratio was determined to be $85 \%$ in our series. As Douglas reports, Tsai found $87 \%$ of functional results ranged from adequate to excellent after ulnar nerve repair with concomitant patent ulnar artery repair, compared to $33 \%$ for thrombosed arterial repair. ${ }^{[10]}$ Leclerq has also argued that when associated artery repair remained patent, ulnar nerve repair produced superior outcome. ${ }^{[16]}$ Johnson has argued that cold insensitivity or neuropathic symptoms result from nerve damage. ${ }^{[4]}$

To differentiate symptoms arising from nerve and artery injuries, we re-tested patients who only had ulnar artery and ulnar nerve injury at level of the wrist to evaluate functional healing using QuickDASH score to identify subgroup with standard injury. Doppler US was used to determine vascular patency. All of the patients had undergone surgery at least 6 months prior and all had concomitant flexor carpi ulnaris, flexor digitorum superficialis, or flexor digitorum profundus tendon injury. Statistically significant difference between QuickDASH scores of Group I and Group 2 was found, indicating superior functional healing in non-obliterated group. We believe that better results obtained after nerve repair were related to superior repair technique as well as presence of excellent vascular bed.

In a previous study, researchers demonstrated that significant delay occurred in constitution of normal blood flow after cold stress testing following radial forearm flap. ${ }^{[17]}$ This correlation indicates that cold intolerance might depend on blood supply. Johnson reported that cold-sensitivity, weakness, and paresthesia were independent of patency of damaged arteries and that conditions occurred in patients who had suffered only nerve and/or tendon injury. ${ }^{[4]}$ We found statistically significant difference between patent and thrombosed artery groups with respect to cold intolerance. This finding may indicate that cold intolerance depends on diminished blood flow as much as nerve injury.

Vascular repair that achieved vessel patency yielded better functional outcome with lower QuickDASH score and less cold intolerance. Cold intolerance appears to be related to decreased blood supply as much as nerve dysfunction.

\section{Conflict of interest: None declared.}

\section{REFERENCES}

1. Ballard JL, Bunt TJ, Malone JM. Management of small artery vascular trauma. Am J Surg 1992;164:316-9. Crossre

2. Noaman HH. Management and functional outcomes of combined injuries of flexor tendons, nerves, and vessels at the wrist. Microsurgery 2007; $27: 536-43$. Crossret

3. Lee RE, Obeid FN, Horst HM, Bivins BA. Acute penetrating arterial injuries of the forearm. Ligation or repair? Am Surg 1985;51:318-24.

4. Johnson M, Ford M, Johansen K. Radial or ulnar artery laceration. Repair or ligate? Arch Surg 1993;128:971-5. Crossre

5. Prichayudh S, Verananvattna A, Sriussadaporn S, Sriussadaporn S, Kritayakirana $\mathrm{K}, \mathrm{Pak}$-art $\mathrm{R}$, et al. Management of upper extremity vascular injury: outcome related to the Mangled Extremity Severity Score. World J Surg 2009;33:857-63. Crossret

6. Wali MA. Upper limb vascular trauma in the Asir region of Saudi Arabia. Ann Thorac Cardiovasc Surg 2002;8:298-301.

7. Feliciano DV, Mattox KL, Graham JM, Bitondo CG. Five-year experience with PTFE grafts in vascular wounds.JTrauma 1985;25:71-82.

8. Rich NM, Hughes CW. The fate of prosthetic material used to repair vascular injuries in contaminated wounds J Trauma 1972;12:459-67.

9. McCready RA. Upper-extremity vascular injuries. Surg Clin North Am 1988;68:725-40. Crossret

10. Rothkopf DM, Chu B, Gonzalez F, Borah G, Ashmead D 4th, Dunn R. Radial and ulnar artery repairs: assessing patency rates with color Doppler ultrasonographic imaging. J Hand Surg Am 1993;18:626-8. Crossret

11. Boswick J. Injuries of the radial and ulnar arteries. In Proceedings of the American Society for Surgery of the Hand. J Bone Joint Surg 1967;49:582.

12. Stricker SJ, Burkhalter WE, Ouellette AE. Single-vessel forearm arterial repairs. Patency rates using nuclear angiography. Orthopedics 1989;12:963-5.

13. Sitzmann JV, Ernst CB. Management of arm arterial injuries. Surgery 1984;96:895-901.

14. Hunt CA, Kingsley JR. Vascular injuries of the upper extremity. South Med J 2000;93:466-8. Crossre

15. Bassetto F, Zucchetto M, Vindigni V, Scomparin MA, Corbetti F, Perissinotto E, et al. Traumatic musculoskeletal changes in forearm and hand after emergency vascular anastomosis or ligation. J Reconstr Microsurg 2010;26:441-7. Crossre

16. Leclercq DC, Carlier AJ, Khuc T, Depierreux L, Lejeune GN. Improvement in the results in sixty-four ulnar nerve sections associated with arterial repair. J Hand Surg Am 1985;10:997-9. Crossree

17. Kleinman WB, O'Connell SJ. Effects of the fasciocutaneous radial forearm flap on vascularity of the hand.J Hand Surg Am 1993;18:953-8. 
ORİİNAL ÇALIŞMA - ÖZET

\section{Önkol damar onarımlarının değerlendirilmesi: Arter onarımı ile ilişkili fonksiyonel sonuçlar} Dr. Musa Kemal Keleş, ${ }^{1}$ Dr. Tekin Şimşek, ${ }^{2}$ Dr. Veysel Polat, ${ }^{3}$ Dr. Engin Yosma, ${ }^{2}$ Dr. Ahmet Demir ${ }^{2}$

${ }^{1}$ Dışkapı Yıldırım Beyazıt Eğitim ve Araştırma Hastanesi Plastik, Rekonstrüktif ve Estetik Cerrahi Kliniği, Ankara ${ }^{2}$ Ondokuz Mayıs Üniversitesi Tıp Fakültesi, Plastik Cerrahi Anabilim Dalı, Samsun

${ }^{3}$ Ondokuz Mayıs Üniversitesi Tıp Fakültesi, Radyoloji Anabilim Dalı, Samsun

AMAÇ: Tek damar yaralanması sonrası önkol damar onarımlarında, çalışan ve tıkalı arter onarımlarının geç dönem sonuçlarını karşılaştıran az sayıda çalışma vardır. Bu çalışmadaki amacımız önkol damar onarımlarının geç dönem sonuçlarını QuickDASH skoru ve renkli Doppler ultrason ile karşılaştırmaktı.

GEREÇ VE YÖNTEM: Yüz altmış altı ön kol arter yaralanması olan hastalar tarandı. Aynı yaralanması olan 30 hasta (ulnar arter, ulnar sinir ve fleksör zon beş tendon yaralanması) renkli Doppler ve QuickDASH skorlaması için geri çağrıldılar.

BULGULAR: Hastalar renkli Doppler sonuçlarına göre iki gruba ayrıldılar; çalışan damarı olanlar (grup I) ve tıkalı damarı olanlar (grup 2). Bu iki grubun QuickDASH skorları arasında istatistiksel analiz yapıldı. Aradaki fark istatistiksel olarak anlamlıydı. Grup I'de (24.27) grup 2'ye (36.34) göre daha düşük QuickDASH skoru vardı. Bu çalışan damarı olan hastalarda daha iyi sonuç alındığını göstermekteydi.

TARTIŞMA: Sonuç olarak, vasküler onarım yapılan hastalarda daha iyi fonksiyonel sonuç alınabilmektedir.

Anahtar sözcükler: Fonksiyonel sonuçlar; önkol yaralanması; sinir yaralanması; soğuk intoleransı; vasküler yaralanma.

Ulus Travma Acil Cerrahi Derg 2017;23(2):117-121 doi: 10.5505/tjtes.2016.36080 